\title{
Acipensins - Novel Antimicrobial Peptides from Leukocytes of the Russian Sturgeon Acipenser gueldenstaedtii
}

\author{
O. V. Shamova',3, D. S. Orlov1,3, S. V. Balandin'2,4, E. I. Shramova², E. V. Tsvetkova ${ }^{3}$, \\ P. V. Panteleev², Yu. F. Leonova², A. A. Tagaev², V. N. Kokryakov'1,3, T. V. Ovchinnikova 2,4,* \\ ${ }^{1}$ Institute of Experimental Medicine, Northwest Branch of the Russian Academy of Medical Sciences, \\ Academician Pavlov Street, 12, Saint-Petersburg 197376, Russia \\ ${ }^{2}$ Shemyakin and Ovchinnikov Institute of Bioorganic Chemistry, Russian Academy of Sciences, \\ Miklukho-Maklaya Street, 16/10, Moscow 117997, Russia \\ ${ }^{3}$ Saint-Petersburg State University, Universitetskaya Embankment, 7/9, Saint-Petersburg 199034, \\ Russia \\ ${ }^{4}$ Moscow Institute of Physics and Technology (State University), Department of Physicochemical \\ Biology and Biotechnology, Institutskii Pereulok, 9, Dolgoprudny 141700, Moscow Region, Russia \\ *E-mail: ovch@ibch.ru \\ Received 11.10.2014 \\ Copyright () 2014 Park-media, Ltd. This is an open access article distributed under the Creative Commons Attribution License, which permits \\ unrestricted use, distribution, and reproduction in any medium, provided the original work is properly cited.
}

\begin{abstract}
Antimicrobial peptides (AMPs) play an important role in the innate defense mechanisms in humans and animals. We have isolated and studied a set of antimicrobial peptides from leukocytes of the Russian sturgeon Acipenser gueldenstaedtii belonging to a subclass of chondrosteans, an ancient group of bony fish. Structural analysis of the isolated peptides, designated as acipensins (Ac), revealed in leukocytes of the Russian sturgeon six novel peptides with molecular masses of 5336.2 Da, 3803.0 Da, 5173.0 Da, 4777.5 Da, 5449.4 Da, and 2740.2 Da, designated as Ac1-Ac6, respectively. Complete primary structures of all the isolated peptides were determined, and the biological activities of three major components - Ac1, Ac2, and Ac6 - were examined. The peptides Ac1, Ac2, Ac3, Ac4, and Ac5 were found to be the N-terminal acetylated fragments 1-50,1-35, 1-49, 1-44, and 1-51 of the histone H2A, respectively, while Ac6 was shown to be the 62-85 fragment of the histone H2A. The peptides Ac1 and Ac2 displayed potent antimicrobial activity towards Gram-negative and Gram-positive bacteria (Escherichia coli ML35p, Listeria monocytogenes EGD, MRSA ATCC 33591) and the fungus Candida albicans 820, while Ac6 proved effective only against Gram-negative bacteria. The efficacy of Ac 1 and Ac2 towards the fungus and MRSA was reduced upon an increase in the ionic strength of the solution. Ac1, Ac2, and Ac6, at concentrations close to their minimum inhibitory concentrations, enhanced the permeability of the E.coli ML35p outer membrane to the chromogenic marker, but they did not affect appreciably the permeability of the bacterial inner membrane in comparison with a potent pore-forming peptide, protegrin 1. Ac1, Ac2, and Ac6 revealed no hemolytic activity against human erythrocytes at concentrations of 1 to $40 \mu \mathrm{M}$ and had no cytotoxic effect (1 to $20 \mu \mathrm{M}$ ) on K-562 and U-937 cells in vitro. Our findings suggest that histone-derived peptides serve as important anti-infective host defense molecules.

KEYWORDS innate immunity; antimicrobial peptides; sturgeon leukocytes; histone H2A derivatives; acipensin. ABBREVIATIONS Ac - acipensin, AMP - antimicrobial peptides, CFU - colony forming units, EDTA - ethylenediaminetetraacetic acid, HNP - human neutrophil peptide (alpha-defensin), MIC - minimum inhibitory concentration, MRSA - methicillin resistant $S$ taphylococcus aureus, ONPG - ortho-nitrophenyl $\beta$ - $D$-galactopyranoside, PAGE - polyacrylamide gel electrophoresis, PBS - phosphate buffered saline, PCR - polymerase chain reaction, PG-1 - protegrin 1, SDS - sodium dodecyl sulfate, TFA - trifluoroacetic acid, TSB - trypticase soy broth; MALDI-TOF-MS - matrix-assisted laser desorption ionization time of flight mass spectrometry; Tris - tris (hydroxymethyl) aminomethane.
\end{abstract}

\section{INTRODUCTION}

Antimicrobial peptides (AMPs) of the innate immune system play an essential role in the anti-infective protection of humans and animals [1]. These molecular factors of innate immunity are of particular importance in providing protective functions to lower vertebrates (fish, amphibians), because the system of adaptive immunity in poikilothermic animals cannot ensure a sufficiently rapid and effective response (antibody formation) to infection at a low temperature in the environment. Therefore, an investigation of the antimicrobial peptides of fish phagocytes and mucous coats is 
important for explaning the biological role of this group of physiologically active substances in anti-infective immunity.

To date, the AMPs (defensins, cathelicidins, etc) of phagocytes and barrier epithelium of various mammals, birds, and amphibians have been described. Information on fish AMPs remains limited and mostly relates to investigation of the compounds isolated from the mucus, skin, gills, kidneys, spleen, and gastrointestinal tract [2]. For example, pleurocidins [3, 4], which are a group of linear antimicrobial peptides with an $\alpha$-helix conformation and a positive charge of the molecule, were isolated from the mucus of the Pleuronectes americanus flounder. A peptide called pardaxin was isolated from the mucous secretions of another flounder species, Pardachirus marmoratus [5]. The peptide hepcidin containing four intramolecular disulfide bridges was isolated from the gills of the hybrid striped bass [6]. Later, hepcidins were found in other fishes. An antimicrobial peptide, misgurin, with broad-spectrum microbicidal activity was obtained from the skin mucus of the loach (mudfish) Misgurnus anguillicaudatus [7].

Peptides of the $\alpha$-defensin family have not yet been found in fish. However, in recent years, data on $\beta$-defensins of bony fish have appeared: these peptides were found in epithelial cells of the digestive tract, gills, and spleen of the Chinese perch Siniperca chuatsi [8], in the liver of the orange-spotted grouper Epinephelus coioides [9], and in the skin and gills of the carp Cyprinus carpio L. [10]. Peptides of the cathelicidin family have been found in the rainbow trout and other salmon and cod species [11-15].

Peptides that are histone derivatives have been found in the skin and mucous coats of some fishes. For example, antimicrobial peptides that are $\mathrm{N}$-terminal parts of histone H2A were isolated from the skin mucus of the Atlantic halibut (Hippoglossus hippoglossus L.) and the Amur catfish Parasilurus asotus and called hipposin [16] and parasin 1 [17], respectively. An antimicrobial protein (SAM) with a molecular weight of 20,734 Da that appeared to be histone H1 was isolated from the liver of the Salmo salar salmon [18].

Therefore, to date, a number of antimicrobial peptides have been described that were isolated from the mucous coats, skin, digestive tract, gills, liver, and spleen of fish. However, there is actually a scarcity of data on AMPs from fish blood leukocytes. Therefore, the aim of this study was to investigate the structural properties and biological activity of antimicrobial peptides from blood leukocytes of the Russian sturgeon Acipenser gueldenstaedtii, a member of the subclass Chondrostei, the oldest group of bony fish (Osteichthyes).

\section{EXPERIMENTAL}

\section{Reagents}

We used acrylamide, N,N'-methylene-bis-acrylamide (Sigma, USA), urea, sodium chloride, tris(hydroxymethyl)aminomethane, MTT (3-[4,5-dimethyl-2-thiazolyl]-2,5-diphenyl-2H-tetrazolium bromide), agarose, trypticase soy broth, trifluoroacetic acid, heptafluorobutyric acid, o-nitrophenyl- $\beta$-D-galactopyranoside (Sigma, USA); acetic acid (Vekton, Russia); media and sera for cell cultures (Biolot, Russia); Saburo medium (Pharmacotherapy Research Center, Russia); and enzymes and buffers for PCR and genetic engineering (Thermo Fisher Scientific, USA). Antimicrobial peptides were used as standards: chemically synthesized protegrin 1 kindly provided by Professor Robert Lehrer (University of California, Los Angeles, USA), human defensin HNP-1 and bactenecin 5 isolated from human and goat blood leukocytes, respectively, using the method described previously [19].

\section{Isolation and purification of antimicrobial peptides} from leukocytes of the Russian sturgeon

Blood from A. gueldenstaedtii sturgeons, caught in the Volga delta (Alexandrovskiy sturgeon plant), was stabilized by heparin and kept in vessels for $6 \mathrm{~h}$ for delamination, after which the buffy coat was pipetted off and washed twice with saline, followed by centrifugation at $400 \mathrm{~g}$ for $5 \mathrm{~min}$. The resulting precipitate was homogenized. Extraction of proteins from the leukocyte-rich suspension was carried out in $20 \%$ acetic acid at $4{ }^{\circ} \mathrm{C}$ under magnetic stirring for $20 \mathrm{~h}$. The homogenate was then centrifuged at 15,000 g for $1 \mathrm{~h}$. The supernatant was collected and subjected to ultrafiltration through the YM-10 membrane using a device from Amicon (USA). The resulting material containing peptides and low-molecular-weight proteins with molecular weights under 10-12 kDa was concentrated to $1 \mathrm{~mL}$ by ultrafiltration through the YM-0.5 membrane and loaded onto an electrophoretic column (a sample was preliminarily added with urea to a concentration of $3 \mathrm{M}$ ) for separation of the proteins by preparative electrophoresis (EP). Preparative EP with continuous elution of proteins was performed in a $12.5 \%$ polyacrylamide gel (PAAG) in an acidic buffer system in the presence of urea [20] using a Bio-Rad cell (USA). Protein fractions eluted from the column were analyzed in the presence of sodium dodecyl sulfate [21] by analytical EP, which was carried out in PAAG plates on a Hoeffer device (USA). The solution absorbance of each fraction was measured at $280 \mathrm{~nm}$, and the antimicrobial activity was determined. The fractions with antimicrobial activity were collected, and the peptides present in them were separated by means of several successive cycles of reverse phase 
high-performance liquid chromatography (RP-HPLC) on a Gold System instrument (Beckman, USA) using Vydac C-18 columns $(4.6 \times 250 \mathrm{~mm} ; 10 \times 250 \mathrm{~mm}$, the diameter of sorbent particles was $5 \mu \mathrm{m}$ ), eluting peptides with the gradient of acetonitrile concentration using different counterions $(0.1 \%$ trifluoroacetic acid or $0.13 \%$ heptafluorobutyric acid). The fractions obtained by RP HPLC were lyophilized by centrifugation under vacuum using a SpeedVac device (Savant, USA). Evaluation of the purity was performed by analytical EP, MALDI TOF mass spectrometry, and analytical RP HPLC. The protein concentration in the extracts from sturgeon leukocytes and in the purified peptide samples was determined by the Bradford method and the Wolf method using the following equation: peptide concentration $(\mu \mathrm{g} / \mathrm{mL})=\left(\mathrm{A}_{215}-\mathrm{A}_{225}\right) \times 144$ [22].

Evaluation of peptide antimicrobial activity by radial diffusion in agarose gels

The antibiotic effect of the peptides isolated from leukocytes was measured by the method proposed by Lehrer et al. [23]. The antimicrobial activity of the samples towards a number of Gram-negative and Gram-positive bacteria, as well as one of the fungi, was determined. The following strains of bacteria were used: Gram-negative bacterium Escherichia coli ML35p, Gram-positive bacteria: Listeria monocytogenes EGD and MRSA ATCC 33591 (methicillin resistant Staphylococcus aureus), and fungus Candida albicans 820 . The bacteria were grown on a solid medium containing a 3\% trypticase soy broth (Sigma, USA); the fungi were grown in a medium containing $3 \%$ Saburo. When E. coli ML-35P was cultured, the medium was supplemented with $100 \mu \mathrm{g} / \mathrm{mL}$ ampicillin and the medium for MRSA ATCC 33591 was supplemented with $6 \mu \mathrm{g} / \mathrm{mL}$ oxacillin. Microorganism strains were kindly provided by Professor Robert Lehrer (University of California, Los Angeles, USA).

The microorganisms were cultured for $16-18 \mathrm{~h}$ in a medium containing a $3 \%$ trypticase soy broth (TSB) solution at $37^{\circ} \mathrm{C}$. Bacterial suspension aliquots were taken from the resulting culture, transferred to the fresh $3 \%$ TSB solution, and incubated at $37{ }^{\circ} \mathrm{C}$ for $2.5 \mathrm{~h}$ to obtain microorganisms in the logarithmic growth phase. The overnight culture was used in experiments with the fungus C. albicans. Microorganism suspensions were further centrifuged at $400 \mathrm{~g}$ for $10 \mathrm{~min}$, the precipitate was washed twice with a $10 \mathrm{mM}$ sodium phosphate buffer (PBS), $\mathrm{pH} 7.4$, and re-suspended in $3 \mathrm{~mL}$ of the same buffer. To prepare agarose gels containing microorganisms, the volume of the suspension with $4 \times 10^{6}$ cells was calculated [23]. The number of bacterial cells was evaluated by measuring the suspension optical density at $620 \mathrm{~nm}$ (it was assumed that the optical density of
0.2 corresponds to $5 \times 10^{7} \mathrm{CFU} / \mathrm{mL}$ ). Another equation was used for fungi: the optical density of 1 at $450 \mathrm{~nm}$ corresponds to $2.86 \times 10^{7} \mathrm{CFU} / \mathrm{mL}$ [23]. The calculated amount of microorganism suspension was added to $8 \mathrm{~mL}$ of a sterile $1 \%$ agarose solution in a $10 \mathrm{mM}$ sodium phosphate buffer (in some experiments, $100 \mathrm{mM} \mathrm{NaCl}$ ), $\mathrm{pH}$ 7.4 , at a temperature of $43^{\circ} \mathrm{C}$. The resulting mixture was poured into a sterile plastic Petri dish with a diameter of $90 \mathrm{~mm}$, wherein the mixture was solidified to form an agarose gel. Holes with a diameter of $2 \mathrm{~mm}$ were perforated in the agarose gels. Wells were filled with the analyzed samples (serial (two-fold) dilutions of the peptides in a $0.01 \%$ aqueous acetic acid solution and a control, $0.01 \%$ acetic acid without peptides) and incubated at $37^{\circ} \mathrm{C}$ for $3 \mathrm{~h}$. During incubation, the peptides diffused from the wells into the agarose gels. After completing incubation, a $1 \%$ agarose solution containing a 6\% trypticase soy broth was applied to the agarose gel surface. The dishes were then incubated for more $20 \mathrm{~h}$ at $37^{\circ} \mathrm{C}$. To quantify the peptide antibiotic activity, the diameter of the microbial growth inhibition zone around the wells was measured, taking $0.1 \mathrm{~mm}$ as the unit, and 20 units were subtracted, which corresponded to the well diameter, from the measured value. The minimum inhibitory concentration (MIC) was determined for each peptide by plotting the dependence of the peptide antimicrobial activity on their concentration. The value obtained for the intersection of the plot of the linear regression of each peptide with the $\mathrm{X}$ axis (peptide concentration in $\mu \mathrm{M}$ ) was taken as the MIC. Two parallel samples were tested in each experiment. Experiments were performed in triplicate, and the arithmetic mean of the obtained MIC \pm standard deviation was calculated.

Evaluation of the peptide's effect on the permeability of the outer and cytoplasmic membranes of E. coli ML35p

The E. coli ML35p strain used in this method is characterized by a lack of lactose permease (enzyme transporting lactose into the cell), with the synthesis of $\beta$-galactosidase in the bacterium cytoplasm being constitutive, not inducible as in most bacteria. Furthermore, the $\beta$-lactamase enzyme is present in the periplasmic space of E. coli ML35p [24]. The state of the cytoplasmic and outer membranes of E. coli ML35p was judged by their permeability to chromogenic markers, o-nitrophenyl- $\beta$ - $D$-galactopyranoside (ONPG) and nitrocefin, which are substrates of $\beta$-galactosidase and $\beta$-lactamase, respectively. A modification of the previously described procedure was used [25]. If the medium surrounding the bacteria contains substrates of $\beta$-galactosidase or $\beta$-lactamase, the enzymatic reaction involving these substrates can occur only if they are able to penetrate through the bacterial membranes. If the outer 
and cytoplasmic membranes of the bacteria, under the action of some damaging agent, such as an antimicrobial peptide, become permeable to the substrates, then the chromogenic products of substrate hydrolysis by intracellular enzymes pass into the incubation medium. The optical density of the medium at 496 or $420 \mathrm{~nm}$ (absorption maximum of the chromogenic products of hydrolysis of nitrocefin or ONPG, respectively) increases, which enables monitoring, in real time, of the process of damage to the outer and cytoplasmic membranes of the bacteria by the antimicrobial agent. Sample composition $(100 \mu \mathrm{L}): 2.5 \mathrm{mM}$ ONPG or $20 \mu \mathrm{M}$ nitrocefin; $2.5 \times 10^{7}$ $\mathrm{CFU} / \mathrm{mL}$ of bacteria; $0.01 \mathrm{M}$ Na-phosphate buffer, $\mathrm{pH}$ $7.4 ; 0.03 \% \mathrm{TSB}$; the peptides at a concentration that is equal to their minimum inhibitory concentration under these conditions and is measured by a standard colony count method. The controls contained equal volumes of the solvent $(0.01 \%$ acetic acid) instead of preparations. The samples were added into the wells of a 96 -well plate, and the solution absorbance was measured at 496 and $420 \mathrm{~nm}$ using a SpectraMax 250 spectrophotometer (Molecular Devices, USA) at $37{ }^{\circ} \mathrm{C}$ and under periodic shaking of the plates for $2 \mathrm{~h}$. The data were processed with the Sigma Plot 11 software. The plots present the results of a typical experiment: each point is the average of two values obtained for duplicate samples. The experiments were performed in triplicate, and the curve pattern was similar for all three series.

Analysis of peptide hemolytic activity

Blood from healthy donors was collected in plastic tubes, using heparin as an anticoagulant and centrifuged at $250 \mathrm{~g}, 4^{\circ} \mathrm{C}$, for $10 \mathrm{~min}$. The supernatant was removed, and the pellet was added with $10 \mathrm{~mL}$ of buffered saline (PBS), $\mathrm{pH}$ 7.4, with $4 \mathrm{mM}$ EDTA and centrifuged at $250 \mathrm{~g}, 4{ }^{\circ} \mathrm{C}$, for $10 \mathrm{~min}$. The precipitate was washed 3 times with PBS using centrifugation as described above. $280 \mu \mathrm{L}$ of the erythrocyte precipitate (the precipitate was assumed to be $100 \%$ red blood cells) was adjusted to $10 \mathrm{~mL}$ with cold PBS to obtain a $2.8 \%$ suspension. The analyzed samples were added with $27 \mu \mathrm{L}$ of the erythrocyte suspension and $3 \mu \mathrm{L}$ of the test peptide at various concentrations in PBS. To prepare a positive control (100\% erythrocyte lysis), 27 $\mu \mathrm{L}$ of the erythrocyte solution was added with $3 \mu \mathrm{L}$ of a surfactant (10\% Triton X-100). To prepare a negative control ( $0 \%$ erythrocyte lysis), $27 \mu \mathrm{L}$ of the erythrocyte solution was added with $3 \mu \mathrm{L}$ of PBS. Samples in triplicate were incubated at $37^{\circ} \mathrm{C}$ for $30 \mathrm{~min}$, and the reaction was terminated by adding $75 \mu \mathrm{L}$ of ice-cold PBS. The samples were centrifuged at $5,000 \mathrm{~g}, 4^{\circ} \mathrm{C}$, for $4 \mathrm{~min}$, and the supernatant was collected and added to the wells of a 96 -well plate (Corning, USA). The sample's optical densities at $540 \mathrm{~nm}$ were measured on a
SpectraMax 250 spectrophotometer (Molecular Devices, USA). The erythrocyte hemolysis parameters were calculated as a percentage according to the equation:

$\%$ Hemolysis $=\left(\left(\mathrm{A}_{\text {exper }}-\mathrm{A}_{\text {control }}\right) /\left(\mathrm{A}_{\text {total }}-\mathrm{A}_{\text {control }}\right)\right) \times 100 \%$,

where $\mathrm{A}_{\text {exper }}$ and $\mathrm{A}_{\text {control }}$ are the supernatant absorbance obtained for treated with the peptides and untreated ( $0 \%$ lysis) erythrocytes, respectively, and $\mathrm{A}_{\text {total }}$ is the supernatant absorbance for red blood cells treated with Triton X-100 (100\% lysis).

\section{MTT test}

The effect of the peptides on cell viability was examined by the MTT assay [26]. This test is based on the ability of dehydrogenases from living cells to reduce colorless forms of 3-(4,5-dimethylthiazol-2-yl)-2,5-diphenyltetrazolium bromide (MTT reagent) or 3-(4,5-dimethylthiazol-2-yl)-2,5-diphenyl-2H-tetrazolium bromide to a blue formazan crystal. The cultured cell lines K-562 (human erythroleukemia cells) and U-937 (human histiocytic lymphoma cells) were used in the experiments. The cell suspensions were placed into the wells of 96well plates (Orange Scientific, Belgium) in a RPMI-1640 medium, 20,000 cells per well. The cells were added with $10 \mu \mathrm{L}$ of a peptide solution (in RPMI-1640 medium) at various concentrations in quadruplicate. Control samples were added with $10 \mu \mathrm{L}$ of the medium instead of the peptides. The plates were then placed in a $\mathrm{CO}_{2}$ incubator for $20 \mathrm{~h}$. Three hours before the end of incubation, the plate wells were added with $10 \mu \mathrm{L}$ of the MTT solution ( $5 \mathrm{mg} / \mathrm{mL}$ in PBS). After incubation, the wells were added with $100 \mu \mathrm{L}$ of isopropanol with $0.04 \mathrm{M}$ HCI, stirred, and the optical density of the solution in plate wells was measured at $540 \mathrm{~nm}$ (subtracting the absorbance at 690 $\mathrm{nm}$ as a background) on a Spectra Max 250 spectrophotometer (Molecular Devices, USA). The significance of the differences between groups was evaluated using the Wilcoxon-Mann-Whitney U-test. In all calculations, the $95 \%$ confidence level $(\mathrm{P}<0.05)$ was considered as significant.

\section{Mass Spectrometry}

The molecular weights of the isolated peptides were determined on a Reflect III MALDI-TOF mass spectrometer (Bruker, Germany) equipped with a UV-laser with a wavelength of $336 \mathrm{~nm}$. 2,5-dihydroxybenzoic acid (Sigma, Germany) in 20\% acetonitrile and $0.1 \%$ TFA at a concentration of $10 \mathrm{mg} / \mathrm{mL}$ was used as a matrix.

\section{Determination of the $\mathbf{N}$-terminal}

amino acid sequence

The amino acid sequence was determined by using a Procise cLC 491 protein sequencing system (Applied 
Biosystems, USA). The phenylthiohydantoin derivatives of amino acid residues were identified on a $120 \mathrm{~A}$ PTH analyzer (Applied Biosystems, USA).

Deblocking of $\mathbf{N}$-terminal amino acid residues

Deacylation of the N-terminal acetylserine residue was performed according to the procedure in [27] on an inert carrier, Immobilon, used for automatic protein sequencing. A peptide sample was applied to Immobilon, placed in a $500 \mu \mathrm{L}$ test tube, damped with $30 \mu \mathrm{L}$ of $25 \%$ TF A solution, and then incubated in a sealed test tube at $45{ }^{\circ} \mathrm{C}$ for $4 \mathrm{~min}$. Peptide-coated Immobilon was dried in an open test tube at $20{ }^{\circ} \mathrm{C}$ for $5 \mathrm{~min}$ and at $45^{\circ} \mathrm{C}$ for another $10 \mathrm{~min}$ and then incubated in a sealed test tube at $45{ }^{\circ} \mathrm{C}$ for $72 \mathrm{~h}$. The resulting sample was used for automated sequencing of the peptide.

\section{Isolation of genomic DNA}

Sturgeon tissue fragments were incubated in the TNES buffer (10 mM Tris-HCl, pH 7.5; $400 \mathrm{mM} \mathrm{NaCl} ; 100 \mathrm{mM}$ EDTA, $0.6 \%$ SDS) with $10 \mathrm{mg} / \mathrm{mL}$ proteinase $\mathrm{K}$ at $55^{\circ} \mathrm{C}$ for $16 \mathrm{~h}$. After centrifugation at $12,000 \mathrm{~g}$ for $10 \mathrm{~min}$, the supernatant was added with a 0.25 volume of $5 \mathrm{M} \mathrm{NaCl}$ and DNA was precipitated by adding one volume of $95 \%$ ethanol. The precipitate was washed with $80 \%$ ethanol, dried in an open test tube, and dissolved in water. Then, a single purification of DNA was performed with the phenol : chloroform mixture $(1: 1, \mathrm{v} / \mathrm{v})$; the remaining phenol was extracted with an equal volume of chloroform, and DNA was precipitated with $95 \%$ ethanol.

\section{Amplification of nucleotide sequences}

To amplify an internal region of the sturgeon histone $\mathrm{H} 2 \mathrm{~A}$ gene, degenerate primers №1 (ATGTGTGGACG(A,C)GG(C,T)AA(A,G)AC(A,C,T) GG) and №2 (GTCTTCTTGGG(C,G)AG(C,T)AG(C,T) $\mathrm{AC}(\mathrm{G}, \mathrm{T}) \mathrm{GCC})$ were used. PCR was performed with a stepwise reduction in temperature at the stage of primer annealing: $94{ }^{\circ} \mathrm{C}-1 \mathrm{~min} ; 5 \times\left(94{ }^{\circ} \mathrm{C}-30 \mathrm{~s}\right.$, $\left.61{ }^{\circ} \mathrm{C}-40 \mathrm{~s}, 68{ }^{\circ} \mathrm{C}-60\right) ; 5 \times\left(94{ }^{\circ} \mathrm{C}-30 \mathrm{~s}, 58{ }^{\circ} \mathrm{C}-40 \mathrm{~s}\right.$, $\left.68{ }^{\circ} \mathrm{C}-60\right) ; 30 \times\left(94^{\circ} \mathrm{C}-30 \mathrm{~s}, 55^{\circ} \mathrm{C}-40 \mathrm{~s}, 68^{\circ} \mathrm{C}-60 \mathrm{~s}\right)$.

Prior to inverse PCR, the sturgeon genomic DNA was treated with BglII restrictase. Composition of the reaction mixture: $1 \times$ buffer O (Thermo Fisher Scientific), $50 \mathrm{ng} / \mu \mathrm{L}$ DNA, 40 units of BglII (Thermo Fisher Scientific). The reaction was conducted in a volume of $50 \mu \mathrm{L}$ at $37^{\circ} \mathrm{C}$ for $16 \mathrm{~h}$. The reaction products were diluted 25 times with water ( $2 \mathrm{ng} / \mu \mathrm{L}$ of DNA), followed by the ligation reaction conducted in the presence of $10 \mathrm{mM}$ ATP at $4{ }^{\circ} \mathrm{C}$ for $16 \mathrm{~h}$. Then, DNA was precipitated with $95 \%$ ethanol: the precipitate was dissolved in water and used as a template for inverse PCR.

Inverse PCR was conducted using two primer pairs in two stages. At the first stage, primers
№3 (GAGCACAGCGGCCAGATAGA) and №4 (CTGAAATCCTGGAGCTGGC) and the following amplification program were used: $94{ }^{\circ} \mathrm{C}-5 \mathrm{~min}$; $35 \times\left(94{ }^{\circ} \mathrm{C}-30 \mathrm{~s}, 58{ }^{\circ} \mathrm{C}-60 \mathrm{~s}, 72{ }^{\circ} \mathrm{C}-120 \mathrm{~s}\right)$. The resulting product was diluted with water $(1: 100)$ and used as a template for nested PCR with primers №5 (CACGCTGGGCATAGTTTCC) and №6 (GAATCATCCCGCGTCACCTG) under the following conditions: $94{ }^{\circ} \mathrm{C}-5 \mathrm{~min} ; 35 \times\left(94{ }^{\circ} \mathrm{C}-30 \mathrm{~s}, 62{ }^{\circ} \mathrm{C}-60 \mathrm{~s}\right.$, $\left.72{ }^{\circ} \mathrm{C}-120 \mathrm{~s}\right)$.

\section{Cloning and sequencing of PCR products}

PCR products were eluted from low-melting-point agarose and ligated into the $\mathrm{pGEM}-\mathrm{T}$ vector at sticky $\mathrm{T} / \mathrm{A}$ ends (Promega, USA). Manipulations with recombinant DNA were performed according to the reference procedures [28]. Competent cells of the Escherichia coli DH-10B strain (Life Technologies, USA) were used for transformation. The plasmid DNA was isolated by alkaline lysis. DNA sequencing was performed using the ABI PRISM BigDye Terminator v. 3.1 reagent kit, followed by an analysis of the reaction products on a 3730 DNA Analyzer automatic sequencer (Applied Biosystems, USA).

Statistical analysis of results

Data obtained in the study of peptide antimicrobial activity are presented as an arithmetic mean \pm standard deviation. The arithmetic mean was calculated based on three independent experiments, each of which was performed in duplicate. The data were processed with the Statistica 6 software.

\section{RESULTS}

Structural study of AMPs from

leukocytes of the Russian sturgeon

To isolate the antimicrobial peptides from Russian sturgeon leukocytes, a procedure for isolation and purification was used that involved acid extraction of proteins and peptides from leukocytes, ultrafiltration, preparative EP, and reverse-phase high-performance liquid chromatography [29]. The use of this set of methods yielded six purified AMPs with molecular weights of $5,448.8 \mathrm{Da}, 5,336.0 \mathrm{Da}, 5,174.0 \mathrm{Da}, 4,777.6 \mathrm{Da}$, $3,804.0 \mathrm{Da}$, and 2,741.7 $\mathrm{Da}$ determined using MALDI TOF mass spectrometry, with the three peptides with molecular weights of 5,336.0 Da, 3,804.0 Da, and 2,741.7 $\mathrm{Da}$ accounting for the predominant peptide fractions. The described isolation procedure was repeated several times using the blood leukocytes of sturgeons that were caught at different times and were of different ages and genders, with each cycle of isolation resulting in a similar spectrum of the antimicrobial peptides. In some 


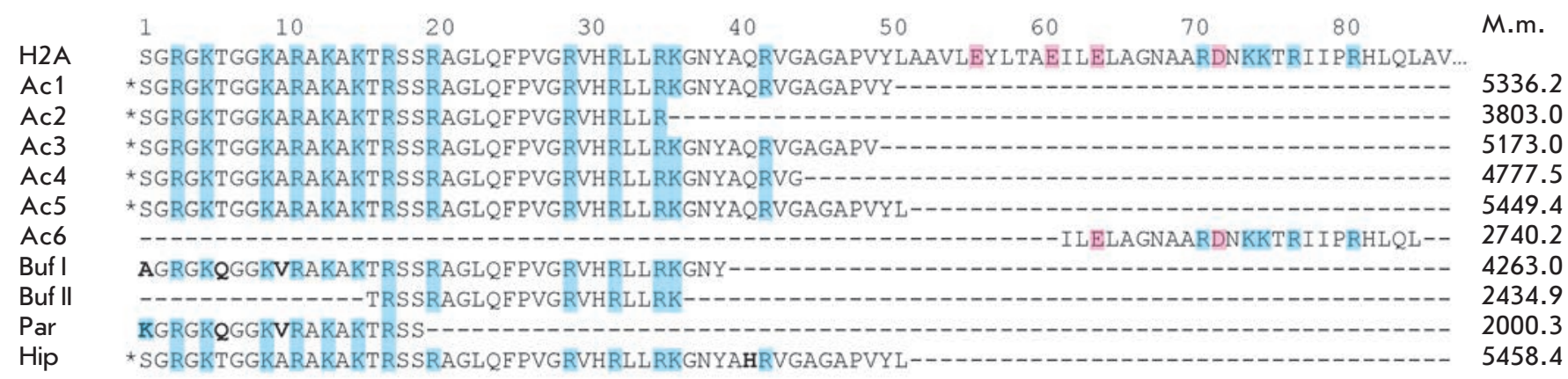

Fig. 1. The structure of acipensins and related AMPs. Histone H2A N-terminal amino acid sequence ( $A$. gueldenstaedtii) and Ac1-Ac6 acipensins are presented. Buf I and Buf II - buforins I and II (Bufo bufo gargarizans); Par - parasin 1 (Parasilurus asotus); Hip - hipposin (Hippoglossus hippoglossus L.). The asterisk ( ${ }^{*}$ ) denotes acetylated N-terminal amino acid residues. M.m. - calculated molecular weights of AMPs, Da. Lys and Arg residues are highlighted with blue; Asp and Glu residues are highlighted with pink. The single amino acid differences between AMP sequences and sturgeon histone $\mathrm{H} 2 \mathrm{~A}$ are shown in bold

experiments, during preparation of the leukocyte-rich suspension and extraction, the serine protease inhibitor, phenylmethylsulfonyl fluoride, was used which did not lead to a significant change in the spectrum of the isolated antimicrobial peptides. The objectives of this study included the structural analysis of the selected peptides and investigation of their biological activity.

A partial N-terminal amino acid sequence of the isolated peptides was established by automated microsequencing. In some cases, sequencing was possible after the chemical reaction of deblocking of the N-terminal amino acid residues. Removal of the acetyl group of the $\mathrm{N}$-terminal acetylserine residue was carried out in an acidic medium using a $25 \%$ solution of TFA. After the removal of the acetyl protection, the $\mathrm{N}$-terminal amino group was easily modified with phenylisothiocyanate, which allowed stepwise degradation of the peptides by the Edman method using a Procise cLC 491 protein sequencing system and identification of the obtained phenylthiohydantoin derivatives of the amino acid residues.

The analysis of the $\mathrm{N}$-terminal peptide sequences from the Russian sturgeon Acipenser guldenstaedtii, which we named acipensins 1-5, using the BLAST software (http://blast.ncbi.nlm.nih.gov/Blast.cgi) demonstrated that they were the $\mathrm{N}$-terminal fragments of a histone of the H2A family, while another peptide, acipensin 6 , was a fragment of the central part of the histone molecule of the same family. These AMPs constitute the dominant part of acid-soluble peptides with antimicrobial activity from sturgeon leukocytes.

To determine the complete primary structure of the acipensins, cloning and sequencing of encoding nucleotide sequences was performed. It is known that the genes of canonical histones, which are most widely present in eukaryotic cells, lack introns, and that their mRNAs lack the 3'-terminal polyA sequence [30]. Only mRNAs of specialized histone variants constituting a minor fraction of these proteins are subjected to polyadenylation. Another feature of the canonical histones is the presence of multiple copies of their genes in the genome. All this makes it preferable to use genomic DNA as a template for the amplification of nucleotide sequences encoding histones. Based on the assumption that the isolated AMPs were products of the partial proteolysis of the dominant fraction of the sturgeon histone $\mathrm{H} 2 \mathrm{~A}$, it was decided to amplify a region of the genomic DNA encoding this histone. Due to the low evolutionary conservation of the untranslated regions flanking this site, the experiment was carried out in two stages. The internal part of the gene with degenerate primers selected for conserved segments of the translated region were first amplified. Cloning and sequencing of the resulting amplicon about $300 \mathrm{bp}$ in length enabled selection of the structure of primers for inverse PCR that was used to amplify the nucleotide sequence of the regions immediately adjacent to the fragment sequenced at the first stage. The amplicon size in this case was about $400 \mathrm{bp}$. The data obtained by DNA sequencing (GenBank KP059880) in combination with the data of the $\mathrm{N}$-terminal amino acid analysis and mass spectrometry allowed us to determine the complete amino acid sequence of acipensins 1-6 (Fig. 1). It was found that Ac1, Ac2, Ac3, Ac4, and Ac5 are the $\mathrm{N}$-terminal acetylated fragments 1-50, 1-35, $1-49,1-44$, and $1-51$ of histone $\mathrm{H} 2 \mathrm{~A}$, respectively, and Ac6 is the fragment $62-85$ of histone H2A. The structural analysis of acipensins $1-6$ showed the presence of 
Table 1. Antimicrobial activity of acipensins Ac1, Ac2, and Ac6*

\begin{tabular}{|c|c|c|c|c|c|c|c|c|}
\hline & \multicolumn{9}{|c|}{ Minimum Inhibitory Concentration, $\mu \mathrm{M}$} \\
\cline { 2 - 9 } & \multicolumn{2}{|c|}{ E.coli ML35p } & \multicolumn{2}{c|}{$\begin{array}{c}\text { Listeria monocytogenes } \\
\text { EGD }\end{array}$} & \multicolumn{2}{c|}{ MRSA ATCC 33591 } & \multicolumn{2}{c|}{ Candida albicans 820 } \\
\cline { 2 - 9 } & $\begin{array}{c}\text { without } \\
\mathrm{NaCl}\end{array}$ & $\begin{array}{c}100 \mathrm{mM} \\
\mathrm{NaCl}\end{array}$ & $\begin{array}{c}\text { without } \\
\mathrm{NaCl}\end{array}$ & $\begin{array}{c}100 \mathrm{mM} \\
\mathrm{NaCl}\end{array}$ & $\begin{array}{c}\text { without } \\
\mathrm{NaCl}\end{array}$ & $\begin{array}{c}100 \mathrm{mM} \\
\mathrm{NaCl}\end{array}$ & $\begin{array}{c}\text { without } \\
\mathrm{NaCl}\end{array}$ & $\begin{array}{c}100 \mathrm{mM} \\
\mathrm{NaCl}\end{array}$ \\
\hline Ac1 & $0.7 \pm 0.1$ & $0.4 \pm 0.1$ & $1.1 \pm 0.2$ & $2.3 \pm 0.4$ & $0.9 \pm 0.2$ & $>40$ & $1 \pm 0.2$ & $>40$ \\
\hline Ac2 & $0.3 \pm 0.1$ & $1.1 \pm 0.2$ & $1.0 \pm 0.2$ & $2.7 \pm 0.3$ & $0.6 \pm 0.1$ & $>40$ & $0.9 \pm 0.1$ & $>40$ \\
\hline Ac6 & $2.5 \pm 0.3$ & $>40$ & $>40$ & $>40$ & $>40$ & $>40$ & $>40$ & $>40$ \\
\hline HNP-1 & $0.8 \pm 0.1$ & $>50$ & $1.0 \pm 0.3$ & $1.1 \pm 0.2$ & $1.7 \pm 0.3$ & $>50$ & $2.1 \pm 0.4$ & $>50$ \\
\hline PG-1 & $0.2 \pm 0.1$ & $0.2 \pm 0.1$ & $0.3 \pm 0.05$ & $0.3 \pm 0.1$ & $0.4 \pm 0.1$ & $0.4 \pm 0.2$ & $0.4 \pm 0.1$ & $1.2 \pm 0.4$ \\
\hline ChBac5 & $0.4 \pm 0.1$ & $0.3 \pm 0.1$ & $0.6 \pm 0.1$ & $1.5 \pm 0.7$ & $0.8 \pm 0.3$ & $>40$ & $0.9 \pm 0.2$ & $>40$ \\
\hline
\end{tabular}

* Data are presented as the minimum inhibitory concentration of peptides in $\mu M$; the peptides were incubated with microorganisms in a $10 \mathrm{mM}$ sodium phosphate buffer, $\mathrm{pH} 7.4$, in one case, and in a $10 \mathrm{mM}$ sodium phosphate buffer, pH 7.4 , containing $100 \mathrm{mM} \mathrm{NaCl}$, in another case. The comparison peptides were porcine protegrin 1 (PG-1), human alphadefensin HNP-1, and goat bactenecin ChBac5.

peptides with calculated molecular weights of $5,336.2$ Da, 3,803.0 Da, 5,173.0 Da, 4,777.5 Da, 5,449.4 Da, and $2,740.2 \mathrm{Da}$, respectively, in sturgeon leukocytes. The calculated molecular weights of acipensins 1-6 were in good agreement with the experimental data of massspectrometry analysis $(5,336.0 \mathrm{Da}, 3,804.0 \mathrm{Da}, 5,174.0$ Da, 4,777.6, 5,448.8 Da, and 2,741.7 Da, respectively).

The literature data indicate that histone $\mathrm{H} 2 \mathrm{~A}$ derivatives have already been isolated from the skin and mucus of lower vertebrates (fish and amphibians). In particular, buforins [31] that are structurally similar to acipensins (Fig. 1) were isolated from the gastric mucosa of the Asian toad Bufo bufo gargarizans and characterized. As previously mentioned, the antimicrobial peptides hipposin and parasin that appeared to be the $\mathrm{N}$-terminal fragments of histone $\mathrm{H} 2 \mathrm{~A}$ were isolated from the mucous coats of bony fishes, the halibut Hippoglossus hippoglossus L. [16], and the Amur catfish Parasilurus asotus [17], respectively.

Analysis of acipensin antimicrobial activity

Antimicrobial activity is believed to be a central functional property of AMPs. The peptides described in the literature (defensins, cathelicidins, etc) have it to different extents: the mechanism of their antibacterial action is diverse. The antimicrobial activity of three major fractions of acipensins (Ac1, Ac2, Ac6) was evaluated by radial diffusion, with experiments being conducted under various conditions: in a medium containing only a $10 \mathrm{mM}$ sodium phosphate buffer with no added salts and in the same medium but with $100 \mathrm{mM}$ sodium chloride (close to the physiological concentration of sodium chloride). This approach aimed at evaluating the impact of an increase in the solution's ionic strength on the efficiency of the antimicrobial activity of peptides was used in many experimental studies of the antimicrobial properties of natural AMPs described in the literature, and its use enables a comparison of the activity of the isolated peptides with the antibiotic effects of other AMPs. The results of the analysis of the acipensin's antimicrobial activity against bacteria Esherichia coli ML-35p, Listeria monocytogenes EGD, methicillin-resistant Staphylococcus aureus (MRSA) ATCC 33591 , and the fungus Candida albicans 820 are presented in Table 1 . The activity of acipensins was studied in comparison with three other AMPs with a different structure and mechanism of antimicrobial action: porcine protegrin 1, human alpha-defensin HNP-1, and goat bactenecin $\mathrm{ChBac5}$. Alpha-defensins are the main antimicrobial peptides, along with cathelicidin LL-37, of human neutrophilic granulocytes. Proline-rich bactenecins are the dominant family of the AMPs of goat and sheep neutrophils. Protegrin 1 (PG-1) of porcine leukocytes, which has a beta-hairpin conformation, is one of the most active peptides, described to date, of animal leukocytes that exhibits a broad spectrum of antimicrobial activity based on its ability to damage the membranes of microorganisms.

As seen from the Table, in a medium with a low ionic strength, acipensins 1 and 2 demonstrate a broad spectrum of action and exhibit a high antimicrobial activity against both Gram-negative and Gram-positive bacteria, as well as the fungus. However, the spectrum of Ac1 and Ac2 activity changes with increasing medium ionic strength: the efficiency of their effect against the Gram-positive bacterium MRSA ATCC 33591 and the fungus Candida albicans 820 is significantly reduced. Ac6 demonstrates an antimicrobial effect only against 
$\mathrm{A}_{486}$

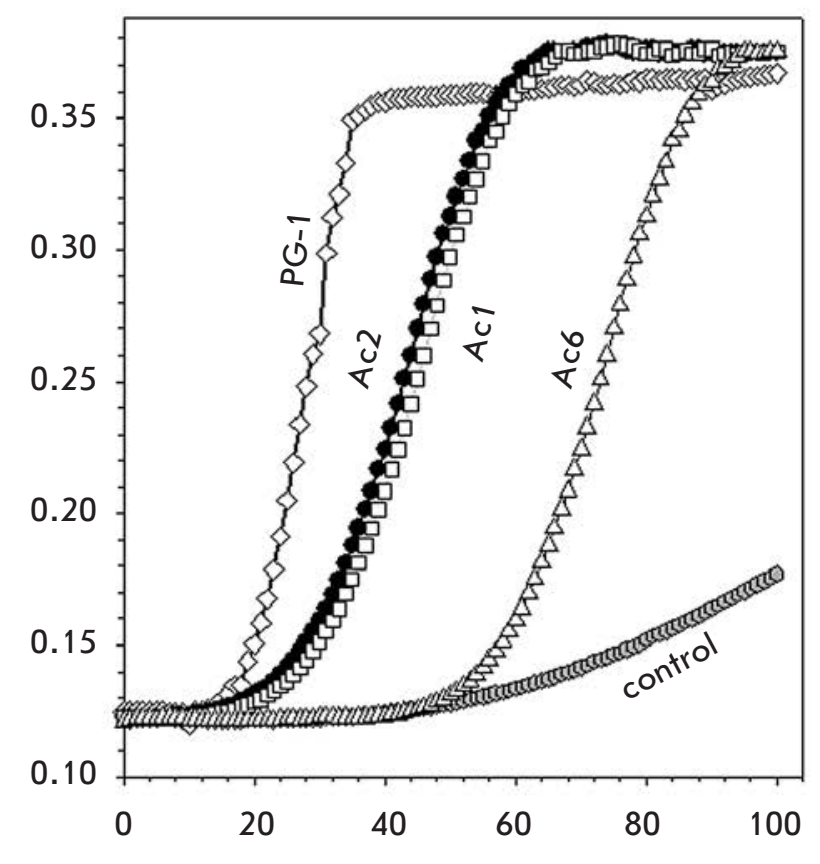

$\mathrm{A}_{420} \quad$ Inner membrane

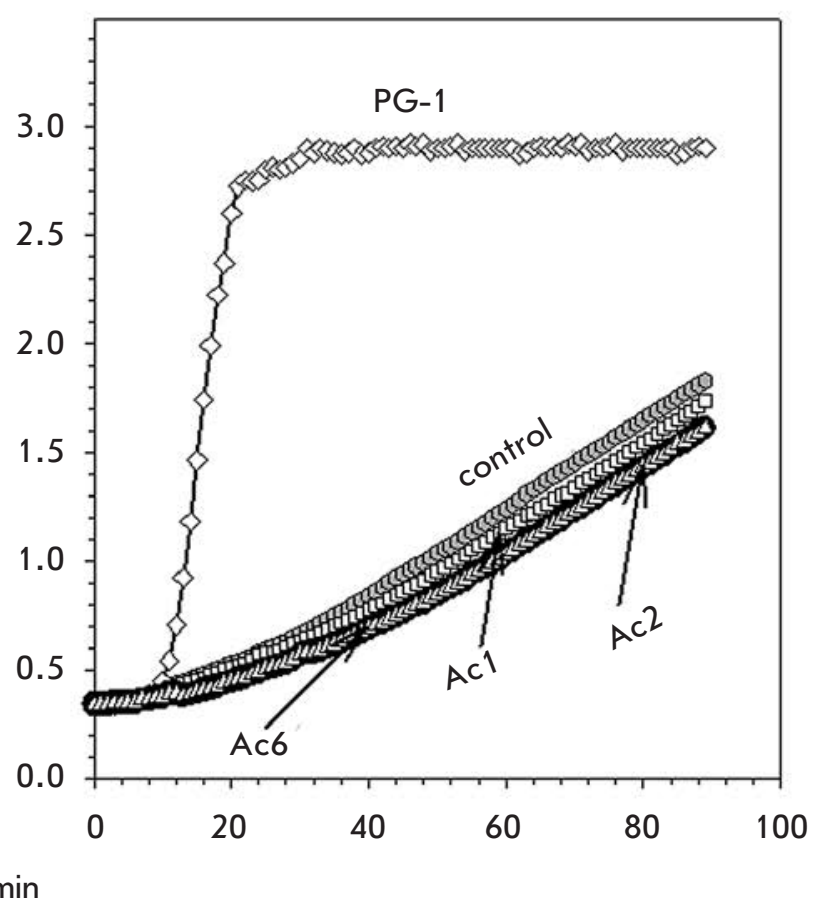

Fig. 2. Kinetics of the changes in the E.coli ML35p membrane permeability to chromogenic markers under the action of antimicrobial peptides. $X$ axis - time of incubation of peptides and bacteria, min. $Y$ axis - optical density of a solution containing chromogenic markers: the nitrocefin hydrolysis product (left panel displaying the outer membrane permeability) and the ONPG hydrolysis product - o-nitrophenol (right panel displaying the inner membrane permeability). The peptides were applied at concentrations equal to their MICs for E.coli ML35p under similar conditions

the Gram-negative bacterium E.coli in a low-ionicstrength medium. The antimicrobial effect of Ac1 and Ac2 differs from that of membrane-active PG-1 and is similar to the effects of bactenecin ChBac5. Bactenecins are known to exhibit antibacterial action mainly against Gram-negative bacteria, and this action is exerted without significant damage to the bacterial membranes and is directed against intracellular targets [14]. Although acipensins do not have a structural similarity with proline rich bactenecins, it may be assumed that the prime targets of their antibacterial action, similarly to bactenecins, are not bacterial membranes. Investigation of the effects of Ac1, Ac2, and Ac6 on the barrier function of bacterial membranes was the next objective of this study.

The effect of acipensins on the permeability of the outer and cytoplasmic membranes of E.coli ML35p to chromogenic markers

Figure 2 presents the kinetics of the action of acipensins 1,2 , and 6 (at a concentration equal to their minimum inhibitory concentration (MIC) against this bacterium) on the outer and inner (cytoplasmic) membranes of E.coli ML35p. The membrane-active peptide PG-1 was used as a standard. Acipensins 1 and 2 have a distinct effect on the permeability of the outer membrane of the bacterium to a chromogenic marker, nitrocefin (as evidenced by an increase in the solution's optical density due to the appearance of a colored product of the nitrocefin cleavage (see Experimental section)), although to a lesser extent than PG-1. An increase in the outer membrane permeability was observed 15-29 $\mathrm{min}$ after the addition of Ac1 and Ac2 to bacteria and 50 min in the case of Ac6. However, an action of all three studied acipensins on the cytoplasmic membrane of E.coli ML35p, evaluated by this method, was hardly observed 90 min after the start of the experiment: the membrane permeability to the chromogenic marker ONPG was unchanged compared to the control values (indicators in samples without peptides). Therefore, these data suggest that the main target of acipensins at concentrations close to the MIC are not the bacterial membranes but intracellular components.

Apart from the antimicrobial activity, most AMPs are known to exhibit a variety of effects on the host cells, including a cytotoxic effect, causing cell death. 
We investigated the possibility of acipensin's toxic effect on cells of a macroorganism.

Acipensin cytotoxic activity against

human cells in vitro

As in most published studies on the cytotoxic activity of various AMPs, human cells are the main subject of the investigation of this peptide's activity, because natural AMPs are considered as promising prototypes of new drugs for use in medicine, and elucidation of the toxicity of these compounds, especially against human cells, is of great importance. We investigated the hemolytic activity of acipensins 1, 2, and 6 against human erythrocytes. Erythrocyte hemolysis was found not to be observed for the studied peptides at concentrations of 1-40 $\mu \mathrm{M}$ (Fig. 3). As in previous experiments, PG-1, which has a high hemolytic activity contrary to that of sturgeon peptides, was used as a positive control. A study of the acipensin effect on the cultured human cell lines K-562 (human erythroleukemia cells) and U-937 (human histiocytic lymphoma cells) revealed that the peptides at concentrations of $1-20 \mu \mathrm{M}$ did not exert toxic effects on the target cells: the proportion of viable cells after their incubation with each of the studied acipensins for $20 \mathrm{~h}$ did not differ from the proportion of viable cells in the control samples.

\section{DISCUSSION}

The discovery, in fish and amphibians, of cationic peptides that exhibit antimicrobial activity and are histone fragments allowed a number of researchers to suggest that these histone derivatives might have a non-nuclear localization and function as antimicrobial protectors [18, 32, 33]. This hypothesis is supported by data on the detection of histone $\mathrm{H} 1$ in the cytosol of human intestinal villus cells [34]. In mice, H1 was found on the macrophage surface, where it acts as a thyroglobulin receptor [35]. Histones H1 (MUMP-1 and MUMP-2) and H2B (MUMP-3) were isolated from the granular fraction of mouse macrophages [36]. In addition, histone H1 was found on the surface of mouse neurons [37], human monocytes [38], and the nonspecific cytotoxic cells of channel catfish (similar to natural killer cells of mammals) [39]. The importance of histones in the course of immune processes became apparent when information about their involvement in the functioning of neutrophil extracellular traps (NETs) emerged [40, 41]. The formation of these structures, first identified in 2004, is the third, along with phagocytosis and secretion of antimicrobial compounds, mechanism of neutrophil killing activity [42]. Extracellular traps are formed during NETosis (controlled cell death, significantly different from necrosis and apoptosis) and are a decondensed chromatin network that includes antimicrobial factors

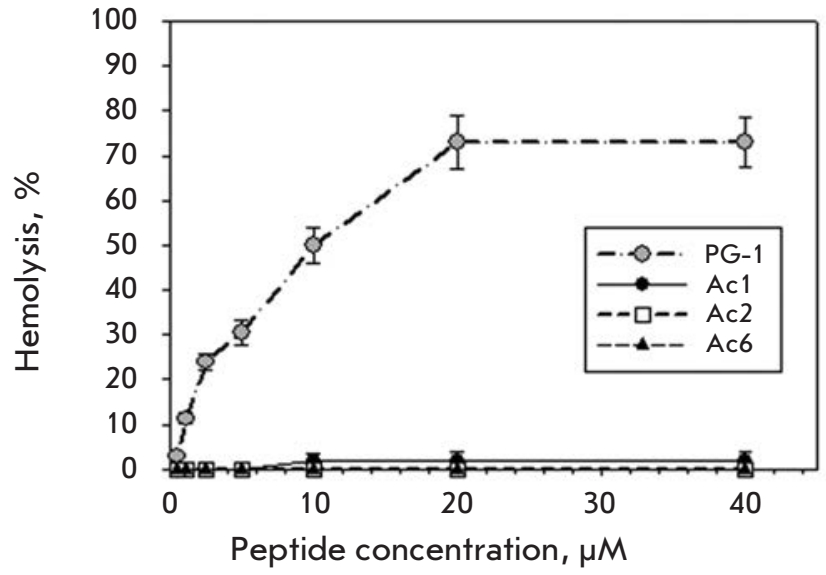

Fig. 3. Hemolytic activity of acipensins. X axis - peptide concentration, $\mu M$. Y axis - percentage of erythrocyte hemolysis calculated by the following equation: $\%$ Hemolysis $=\left(\left(A_{\text {exper }}-A_{\text {control }}\right) /\left(A_{\text {total }}-A_{\text {control }}\right)\right) \times 100 \%$, where $A_{\text {exper }}$ and $A_{\text {control }}$ are the supernatant absorbance obtained for treated and untreated red cells, respectively, and $A_{\text {total }}$ is the supernatant absorbance for red cells treated with $1 \%$ Triton X-100. A strong hemolytic activity of the peptide PG-1 was used as a positive control

of both granular (proteases, AMPs) and nuclear (histones and products of their partial proteolysis) origin. Extracellular traps ensure capture and destruction of pathogenic microorganisms that, for some reason, cannot be neutralized by phagocytosis. Due to the structuring role of DNA, diffusion of antimicrobial factors from the trap is slowed, which enables achievement of high local concentrations of these substances and a reduction in their harmful effect on healthy tissues.

The obtained data on the structural and functional properties of antimicrobial peptides from leukocytes of the Russian sturgeon, acipensins, as histone H2A derivatives confirm the hypothesis that during evolution, derivatives of proteins that usually have a nuclear localization might be selected as endogenous antibiotic peptides in separate groups of animals. This demonstrates a surprising variety of structural AMP families among members of different taxa of the animal world. The most common group of AMPs is known to be members of the defensin family, whose functional activity is realized in phagocytes (neutrophils and macrophages of vertebrates, and amoebocytes and coelomocytes of invertebrates) and at the level of barrier epithelia of the integument and mucosae of animals. However, peptides of the defensin family were not found in sturgeon leukocytes. Defensins are also absent in the phagocytes of certain mammalian species (mouse, cat, dog, sheep and goat). In these species, the function of molecules inactivating phagocytized microbes is performed by 
peptides of the cathelicidin family (bactenecins, protegrins, etc). The peculiarity of the species pattern of the antimicrobial peptides of Russian sturgeon leukocytes is that they are dominated by peptides, histone H2A derivatives, that had not previously been found in fish phagocytes.

Acipensins have a broad spectrum of antimicrobial action like other, currently known histone H2A derivatives: buforin, parasin, hipposin, abhizin (peptide from the Haliotis mollusc) [16, 17, 31, 43]. Unlike parasin and buforin 1, acipensins 1-5 are molecules with an acetylated $\mathrm{N}$-terminus. The hipposin molecule has the same property [16]. Acetylation of the N-terminus was found not to be necessary for the exhibition of antimicrobial activity, because synthetic non-acetylated hipposin turns out to be active [16].

The observed decrease in the antimicrobial activity of acipensins with an increase in the solution ionic strength is characteristic of many AMPs described in the literature: e.g., human alpha-defensins and goat bactenecins. The antimicrobial activity of defensins is known to be able to recover in media containing physiological concentrations of sodium chloride, which results from synergistic action with other AMPs of human neutrophils, in particular, cathelicidin LL-37 [44]. It may be assumed that, along with the constitutively synthesized acipensins, sturgeon leukocytes contain inducible antimicrobial factors whose synthesis is increased during the infectious process, and that can act together with acipensins, which increases the efficiency of the antimicrobial action of AMPs.

The data on the low antimicrobial activity of Ac6 compared to that of Ac1 and Ac2 suggest that these are $\mathrm{N}$-terminal derivatives of histone $\mathrm{H} 2 \mathrm{~A}$ that play a key role in anti-infective protection.

The mechanisms of action of AMP derivatives of histone $\mathrm{H} 2 \mathrm{~A}$ described in the literature are slightly different: the main mechanism of antimicrobial action of buforin 2 is associated with its ability to penetrate into bacterial cells without significant damage to their membranes and to interact with nucleic acids, which leads to inhibition of vital processes in microbial cells and to their death $[45,46]$. However, another peptide, parasin, exerts a pronounced damaging effect on the bacterial membranes [47]. A synthetic analog of hipposin was demonstrated also to have the ability to increase the permeability of bacterial membranes (E. coli ATCC 25922) [48]. Although acipensins have a significant structural similarity to hipposin, no appreciable increase in the permeability of the cytoplasmic membrane of $E$. coli ML35p under the action of acipensins was observed in our experiments. On the one hand, it may be assumed that the difference in the results is related to the fact that other bacterial strains and per- meability markers were used in our study. On the other hand, the decisive role is probably played by the peptide concentration. For example, the dual mode of action [49] was established for proline-rich peptides, in particular bactenecins: at concentrations close to the MIC, the peptides did not have a damaging effect on the membranes, their effects were associated with the impact on intracellular targets, while at concentrations above the MIC, these AMPs, in addition to the inhibition of intracellular processes, disturbed the structural integrity of the membrane. Because concentrations close to the MIC were used in experiments on the evaluation of the acipensin effect on the permeability of bacterial membranes, we may assume that acipensins at higher concentrations, like bactenecin and hipposin, can also disturb the barrier function of bacterial membranes. Finally, it cannot be excluded that the observed discrepancy in the results may be due to those few amino acid substitutions that distinguish Ac1 and Ac2 from the hipposin analog used in [48]. A more detailed investigation of the effect of acipensins on bacterial membranes will be conducted in our future studies using recombinant acipensin analogs.

Similarly to other natural AMP derivatives of histone $\mathrm{H} 2 \mathrm{~A}$, all three studied acipensins (Ac1, Ac2, and Ac6) exhibited no significant cytotoxic activity against the cultured human cells. Further investigation of the interaction of acipensins and their structural analogs with the cells will establish whether they possess the potential to translocate across the eukaryotic cell membranes, as it was demonstrated for buforins [46]. Having similar properties opens prospects for the practical application of the peptides in antitumor therapy as vectors for the delivery of drugs into malignant cells.

\section{CONCLUSION}

A set of antimicrobial peptides called acipensins that are histone $\mathrm{H} 2 \mathrm{~A}$ fragments were for the first time isolated from leukocytes of the Russian sturgeon $A$. gueldenstadti. These peptides have a broad spectrum of antibacterial activity and do not exhibit toxic properties towards host cells. The obtained data contribute to the development of ideas regarding the evolution of the molecular factors of innate immunity and support the assumption of the biological role of histones as protective molecules involved in the implementation of the anti-infective function of the immune system. $\bullet$

\footnotetext{
This work was supported by a grant from the Federal Target Program "Research and Development on Priority Directions of Scientific-Technological Complex of Russia for 2014-2020" (agreement \#14.604.21.0104). Unique identifier for Applied Scientific Research (project) RFMEFI60414X0104.
} 
REFERENCES

1. Kokryakov V.N. Ocherki o vrozhdennom immunutete (Essays on the innate immunity). St-Petersburg: Nauka. 2006. 261 pp. In Russian.

2. Rieger A.M, Barreda D.R. // Dev. Comp. Immunol. 2011. V. 35. № 12. P. 1238-1245.

3. Cole A.M., Weis P., Diamond G. // J. Biol. Chem. 1997. V. 272. № 18. P. 12008-12013.

4. Douglas S.E., Gallant J.W., Gong Z., Hew C. // Dev. Comp. Immunol. 2001. V. 25. № 2. P. 137-147.

5. Shai Y., Fox J., Caratsch C., Shih Y.L., Edwards C., Lazarovici, P. // FEBS Lett. 1988. V. 242. P. 161-166.

6. Shike H., Lauth X., Westerman M.E., Ostland V.E., Carlberg J.M., Van Olst J.C., Shimizu C., Bulet P., Burns J.C // Eur. J. Biochem. 2002. V. 269. P. 2232-2237.

7. Park C., Lee J., Park I., Kim M., Kim S. // FEBS Lett. 1997. V. 411. № 2-3. P. 173-178.

8. Wang G., Li J., Zou P., Xie H., Huang B., Nie P., Chang M. // Fish Shellfish Immunol. 2012. V. 33. № 3. P. 522-531.

9. Guo M., Wei J., Huang X., Huang Y., Qin Q. // Fish Shellfish Immunol. 2012. V. 32. № 5. P. 828-838.

10. Marel Mv., Adamek M., Gonzalez S.F., Frost P., Rombout J.H., Wiegertjes G.F., Savelkoul H.F., Steinhagen D. // Fish Shellfish Immunol. 2012. V. 32. № 3. P. 494-501.

11. Maier V.H., Dorn K.V., Gudmundsdottir B.K., Gudmundsson G.H. // Molecular Immunology. 2008. V. 45. P. 3723-3730. 12. Chang C., Pleguezuelos O., Zhang Y., Zou J., Secombes C. // Infection and Immunity. 2005. V. 73. P. 5053-5064.

13. Chang C., Zhang Y., Zou J., Nie P., Secombes C. // Antimicrobial Agents and Chemotherapy. 2006. V. 50. P. 185-195.

14. Scocchi M., Pallavicini A., Salgaro R., Bociek K., Gennaro R. // Comp. Biochem. Physiol. B Biochem. Mol. Biol. 2009. V. 152. № 4. P. 376-381.

15. Bridle A., Nosworthy E., Polinski M., Nowak B. // PLoS One. 2011. V. 6. №8. e23417.

16. Birkemo G. A., Lüders T., Andersen Ø., Nes I.F., Nissen-Meyer J. Hipposin, a histone-derived antimicrobial peptide in Atlantic halibut (Hippoglossus hippoglossus). // Biochimica et Biophisica Acta. 2003. V. 1646. P. 207-215.

17. Park I.Y., Park C.B., Kim M.S., Kim S.C. // FEBS Lett. 1998. V. 437. P. 258-262.

18. Richards R.C., O’Neil D.B., Thibault P., Ewart K.V. // Biochem. Biophis. Res. Commun. 2001. V. 284. P. 549-555.

19. Shamova O., Orlov D., Stegemann C., Czihal P., Hoffmann R., Brogden K., Kolodkin N., Sakuta G., Tossi A., Sahl H-G. et al. // International Journal of Peptide Research and Therapeutics. 2009. V. 15. № 1. P. 31-35.

20. Harwig S.S., Chen N.P., Park A.S.K., Lehreer R.I. // Anal. Biochem. 1993. V. 208. P. 382-346.

21. Schagger H., von Jagow G. // Anal. Biochem. 1987. V. 166. P. 368-379.

22. Wolf P. // Anal. Biochem. 1983. V. 129. № 1. P. 145-155.

23. Lehrer R.I., Rosenman M., Harwig S.S., Jackson R., Eisenhauer P. // J. Immunol. Methods. 1991. V. 137. № 2. P. $167-73$.

24. Lehrer R., Barton A., Ganz T. // J. Immunol. Methods. 1988. V. 108. P. 153-158.

25. Artamonov A.Yu., Shamova O.V., Kokryakov V.N., Orlov D.S. // Vestnik Sankt-Peterburgskogo Universiteta. 2008.
Ser. 3, N. 2. P. 139-142. In Russian.

26. Mosmann T. // Journal of Immunological Methods. 1983. V. 65. P. 55-63.

27. Wellner D., Panneerselvam C., Horecker B.L. // Proc. Nat. Acad. Sci. 1990. V. 87. P. 1947-1949.

28. Sambrook J., Fritsch E.F., Maniatis T. Molecular Cloning: a laboratory manuals. 2nd ed. New York: Cold Spring Harbor Laboratory Press, 1989. 1626 p.

29. Shamova O.V., Orlov D.S., Ovchinnikova T.V., Sal Kh-G., Tver'yanovich I.A., Popova V.A., Dyubin V.A., Kokryakov V.N. // Fundamentalnye Issledovaniya. 2006. № 1. P. 10-13. In Russian.

30. Marzluff W.F., Wagner E.J., Duronio R.J. // Nat. Rev. Genet. 2008. V. 9. № 11. P. 843-54.

31. Kim H.S., Park C.B., Kim M.S., Kim S.C. // Biochem. Biophys. Res. Commun. 1996. V. 229. № 2. P. 381-7.

32. Kawasaki H., Iwamuro S. // Infect. Disord. Drug Targets. 2008. V. 8. № 3. P. 195-205.

33. Parseghian M., Luhrs K. // Biochem. Cell Biol. 2006. V. 84. № 4. P. 589-604.

34. Rose F.R., Bailey K., Keyte J.W., Chan W.C., Greenwood D., Mahida Y.R.. // Infect. Immun. 1998. V. 66. P. 3255-3263. 35. Brix K., Summa W., Lottspeich F., Herzog V. // J. Clin. Invest. 1998. V. 102. P. 283-293.

36. Hiemstra P.S., Eisenhauer P.B., Harwig S.S., van den Barselaar M.T., van Furth R., Lehrer R.I. // Infect. Immun. 1993. V. 61. P. 3038-3046.

37. Bolton S.J., Perry V.H. // J. Neurocytol. 1997. V. 26. P. 823-831.

38. Holers V.M., Kotzin B.L. // J. Clin. Invest. 1985. V. 76. P. 991-998.

39. Evans D.L., Kaur H., Leary J. 3rd, Praveen K., JasoFriedmann L. // Dev Comp Immunol. 2005. V. 29. № 12. P. 1049-64.

40. Nauseef W.M., Borregaard N. // Nat. Immunol. 2014. V. 15. № 7. P. 602-11.

41. Zawrotniak M., Rapala-Kozik M. // Acta Biochim Pol. 2013. V. 60. № 3. P. 277-84.

42. Brinkmann V., Reichard U., Goosmann C., Fauler B., Uhlemann Y., Weiss D.S., Weinrauch Y., Zychlinsky A. // Science. 2004. V. 303. № 5663. P. 1532-5.

43. De Zoysa M., Nikapitiya C., Whang I., Lee J.S., Lee J. //

Fish Shellfish Immunol. 2009. V. 27. № 5. P. 639-46.

44. Nagaoka I., Hirota S., Yomogida S., Ohwada A., Hirata M. // Inflamm Res. 2000. V. 49. № 2. P. 73-9.

45. Park C.B., Kim H.S., Kim S.C. // Biochem Biophys Res Commun 1998. V. 244. № 1. P. 253-257.

46. Cho J.H., Sung B.H., Kim S.C. // Biochim Biophys Acta. 2009. V. 1788. № 8. P. 1564-9.

47. Koo Y.S., Kim J.M., Park I.Y., Yu B.J., Jang S.A., Kim K.S., Park C.B., Cho J.H., Kim S.C., // Peptides. 2008. V. 29. P. $1102-1108$.

48. Bustillo M.E., Fischer A. L., LaBouyer M.A., Klaips J. A., Webb A.C., Elmore D.E. // Biochim. Biophys. Acta. 2014. V.1838. № 9. P. 2228-2233.

49. Podda E., Benincasa M., Pacor S., Micali F., Mattiuzzo M., Gennaro R., Scocchi M. // Biochim. Biophysi. Acta. 2006. V. 1760. P. $1732-1740$. 